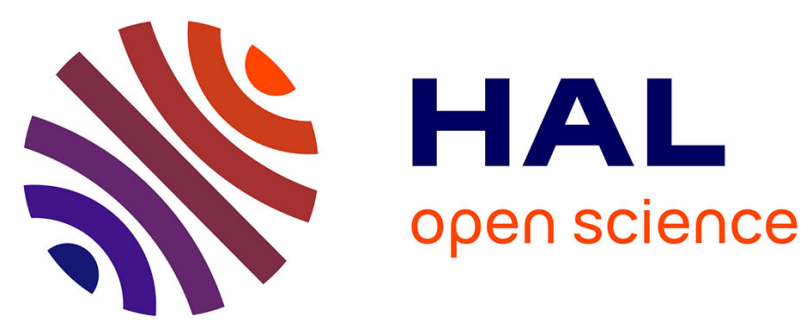

\title{
Direct responses to six generations of selection for ovulation rate or prenatal survival in Large White pigs
}

Adalberto Rosendo-Ponce Rosendo, Tom T. Druet, Jean-Marcel Gogué, Jean

Pierre Bidanel,. Station de Génétique Quantitative Et Appliquée

\section{- To cite this version:}

Adalberto Rosendo-Ponce Rosendo, Tom T. Druet, Jean-Marcel Gogué, Jean Pierre Bidanel, . Station de Génétique Quantitative Et Appliquée. Direct responses to six generations of selection for ovulation rate or prenatal survival in Large White pigs. Journal of Animal Science, 2007, 85, pp.356-364. $10.2527 /$ jas.2006-507 . hal-02653625

\section{HAL Id: hal-02653625 \\ https://hal.inrae.fr/hal-02653625}

Submitted on 29 May 2020

HAL is a multi-disciplinary open access archive for the deposit and dissemination of scientific research documents, whether they are published or not. The documents may come from teaching and research institutions in France or abroad, or from public or private research centers.
L'archive ouverte pluridisciplinaire HAL, est destinée au dépôt et à la diffusion de documents scientifiques de niveau recherche, publiés ou non, émanant des établissements d'enseignement et de recherche français ou étrangers, des laboratoires publics ou privés. 


\title{
Direct responses to six generations of selection for ovulation rate or prenatal survival in Large White pigs
}

\author{
A. Rosendo,*1,2 T. Druet,* J. Gogué, $\dagger$ and J. P. Bidanel ${ }^{* 3}$ \\ *INRA, UR337 Station de Génétique Quantitative et Appliquée, F-78350 Jouy-en-Josas, France; and \\ $\dagger$ INRA, UE332 domaine expérimental de Galle, F-18520 Avord, France
}

\begin{abstract}
Effects of selection for ovulation rate or prenatal survival were examined using data from 3 pigs lines derived from the same base Large White population. Two lines were selected for 6 generations on high ovulation rate at puberty (OR line) or high prenatal survival corrected for ovulation rate in the first 2 parities (PS line). The third line was an unselected control line. Genetic parameters for ovulation rate on the left, right, and both ovaries at puberty (ORPL, ORPR, and ORP, respectively) and at fertilization (ORFL, ORFR, and $\mathrm{ORF}$, respectively), total number of piglets born (TNB) per litter, prenatal survival (PS = TNB/ORF), and PS corrected for ovulation rate $(\mathrm{CPS}=\mathrm{PS}+$ $0.018 \mathrm{ORF}$ ) were estimated using REML methodology. Responses to selection were estimated by computing differences between OR or PS and control lines at each generation using least squares and mixed models methodology. Average genetic trends were computed by regressing line differences on generation number. Realized heritabilities were estimated using standard procedures. Heritability estimates were $0.17,0.11,0.34,0.13$,
\end{abstract}

$0.09,0.33,0.14,0.11$, and $0.17(\mathrm{SE}=0.01$ to 0.03$)$ for ORPL, ORPR, ORP, ORFL, ORFR, ORF, PS, CPS, and TNB, respectively. Realized heritabilities were $0.37 \pm$ 0.08 and $0.10 \pm 0.09$ for ORP and CPS, respectively. The different measures of ovulation rate had strong genetic correlations $\left(r_{g}>0.7\right)$. The ORF had midrange negative genetic correlations with PS and CPS $(-0.45$ \pm 0.07 and $-0.42 \pm 0.08$, respectively). The ORP also had an antagonistic genetic relationship with PS $(-0.26$ $\pm 0.07)$ but was almost independent from CPS (-0.02 \pm $0.11)$. The TNB was moderately correlated with ORP and ORF $\left(\mathrm{r}_{\mathrm{g}}=0.41 \pm 0.09\right.$ for both traits). Average genetic trends in OR and PS lines were, respectively, $0.49 \pm 0.10$ and $0.11 \pm 0.10$ for ORP, and $0.43 \pm 0.11$ and $0.11 \pm 0.11$ for ORF. Responses to selection were slightly superior in the left than in the right ovary. No significant difference was found for PS or CPS in any of the lines. The TNB did not change in the OR line but significantly improved in the PS line $(0.24 \pm 0.11$ piglets/generation).

Key words: litter size, pig, ovulation rate, proflicacy

(C2007 American Society of Animal Science. All rights reserved.

J. Anim. Sci. 2007. 85:356-364

doi:10.2527/jas.2006-507

\section{INTRODUCTION}

Sow prolificacy is a major component of the economic efficiency of pig production (Tess et al., 1983; de Vries, 1989). Yet litter size is a lowly heritable trait (Rothschild and Bidanel, 1998), which is rather difficult to select using standard selection methods. Indeed, direct selection for increased litter size has often produced

\footnotetext{
${ }^{1}$ Financial support was provided to the first author by Consejo Nacional de Ciencia y Tecnologia and Colegio de Postgraduados, Montecillo, Mexico.

${ }^{2}$ Present address: Colegio de Postgraduados, Campus Veracruz km 26.5 carr. Fed. Veracruz-Xalapa, Predio Tepetates, Mpio. de Manlio Fabio Altamirano CP 91700, Apdo. Postal 421, Veracruz, Mexico.

${ }^{3}$ Corresponding author: jean-pierre.bidanel@jouy.inra.fr

Received July 27, 2006.

Accepted September 7, 2006.
}

no (Bolet et al., 1989) or limited responses (Holl and Robison, 2003). Sow prolificacy has been successfully selected in large populations by applying high selection intensities in so-called "hyperprolific" breeding schemes (Legault and Gruand, 1976; Bidanel et al., 1994), resulting in a genetic gain of almost 3 piglets over the last $15 \mathrm{yr}$ in the French Large White breed (Tribout et al., 2003) but remains difficult to select for in smaller populations.

Several authors have proposed to use more highly heritable, indirect criteria to improve the efficiency of selection for litter size; e.g., uterine capacity (Christenson et al., 1987), uterine efficiency (Wilson et al., 1999; Mesa et al., 2005), or components of litter size. In rabbits, selection for uterine capacity has resulted in a significant correlated response on litter size at birth (Argente et al., 1997). In pigs, Johnson et al. (1999) successfully increased litter size after 10 generations 
of selection for an index combining ovulation rate and embryonic survival. Yet, the interest in indirect selection on components of litter size as compared with direct selection on litter size critically depends on the genetic parameters of these components (Perez-Enciso et al., 1996). A selection experiment has been carried out at INRA to estimate the genetic parameters of components of litter size in the French Large White breed.

The objective of this study was to estimate genetic parameters and direct responses to selection for ovulation rate and prenatal survival.

\section{MATERIALS AND METHODS}

\section{Animals and Experimental Design}

Animal care followed the general guidelines outlined in the European animal welfare regulations.

The experiment took place at the INRA experimental herd of Galle (Avord, France). The base generation was constituted by the progeny of a foundation breeding stock consisting of 24 unrelated AI boars and 42 sows. Males and females from this base generation were randomly allocated within litter to 3 contemporary lines. Two lines were then selected for either ovulation rate at puberty (OR line) or prenatal survival over the first 2 parities, corrected for ovulation rate (PS line). The third line was kept as an unselected control line. At each generation, about 50 gilts and 6 to 8 boars from the first litters were kept for breeding. Boars were chosen on a within-sire family basis in the 3 lines. Gilts were randomly chosen within-dam family in the control line and selected on a population basis in the 2 other lines from generation 1 to 6 . In the seventh generation, no selection was practiced, so that breeding animals were chosen at random in the 3 lines.

A mating plan was established to minimize the increase in the average coefficient of inbreeding in the resulting progeny at each generation. In the last generation of the experiment, the average inbreeding coefficient was $15.7,10.9$, and $7.2 \%$ in PS, OR, and control lines, respectively. The greater inbreeding in the PS line was due to the combination of 2 factors: 1 ) as all female progeny from selected sows were kept for breeding, replacement females originated from a lower number of dam families at each generation; and 2) 1 sire family was lost in generation 3 .

The sow herd was managed under a batch farrowing system. At each generation, females were distributed into 7 farrowing batches. These batches then became postweaning and fattening batches of their progeny. Females were inseminated twice at a 24 -h interval. Seven gilts from each line were introduced in each farrowing batch. All females that did not conceive at first mating joined the subsequent farrowing batch where they had the opportunity to be mated once more. Hence, there could be some variation in the number of females per line by batch combination, but each batch included females from the 3 lines. Litters were born in individual farrowing crates. When necessary (e.g., large litters), some piglets could be moved to another crate within the first few hours after farrowing.

Puberty was defined as the first estrus, indicated by a standing response to a teaser boar. Estrus detection, on a daily basis, was initiated at $150 \mathrm{~d}$ of age on and continued until most females reached puberty. Ovulation rate at puberty, estimated by counting the number of corpora lutea visible on the ovaries, was measured in females under general anesthesia by laparoscopy between 10 and $15 \mathrm{~d}$ after the first estrus. The visual exam of the ovaries also allowed checking whether the first detected estrus corresponded to the first ovulation. When a previous ovulation had occurred, which only occurred 16 times over the whole experiment, gilts were removed from the experiment. Females kept for breeding were then mated at 11 mo of age on average, after a synchronization treatment with a progestagen (Regumate-altrenogest, Janssen Animal Health, Saunderton, UK). Ovulation rate was measured, as described above, between 10 and $15 \mathrm{~d}$ after mating. Females were retained to produce 2 litters. The numbers of piglets born alive, stillborn, and mummified were recorded at each farrowing.

The selection criterion in the OR line was ovulation rate at puberty. Gilts were selected on their own performance, and boars were selected on the performance of their dam. The selection criterion in the PS line was the average prenatal survival over the first 2 parities, corrected for ovulation rate $\left[\mathbf{C P S}=0.5\left(\mathrm{CPS}_{1}+\mathrm{CPS}_{2}\right)\right.$, with $\mathrm{CPS}_{\mathrm{i}}=\mathrm{PS}_{\mathrm{i}}+0.018 \mathrm{ORF}_{\mathrm{i}}$, where $\mathrm{i}(=1,2)$ denotes parity number].

\section{Statistical Analyses}

Traits. Nine traits were defined and analyzed from the above mentioned measurements; i.e., the numbers of corpora lutea in the left and right ovaries and their sum at puberty (ORPL, ORPR, and ORP, respectively) and at fertilization (ORFL, ORFR, and ORF, respectively); the total number of fully formed piglets (TNB); the rate of prenatal survival, defined as the ratio of TNB to ORF; and CPS, defined as PS + 0.018ORF. Elementary statistics for the 9 traits studied are given in Table 1.

Least Squares Analyses of Line Differences and Realized Heritabilities. Line $\times$ generation means for each trait were estimated using a linear model, including the fixed effects of generation number (0 to 7), line (OR, PS, or control), line $\times$ generation interaction, parity number ( 1 or 2 , except for traits defined at puberty), and contemporary group within generation. This contemporary group effect consisted of a birth batch effect for traits measured at puberty and of a farrowing batch effect for traits measured at fertilization and at farrowing. Sow or litter inbreeding coefficients, or both, and age at puberty, at fertilization, or at farrowing were also included as linear covariates (Table 2). Quadratic components were tested for each covariate in prelimi- 
Table 1. Overall means and phenotypic SD of the 9 traits analyzed

\begin{tabular}{lccccc}
\hline \hline Trait & No. & Mean & SD & Minimum & Maximum \\
\hline $\begin{array}{l}\text { Ovulation rate at puberty } \\
\quad \text { Left ovary }\end{array}$ & 2,004 & 7.84 & 2.42 & 0 & 23 \\
Right ovary & 2,004 & 6.24 & 2.47 & 0 & 19 \\
$\quad$ Both ovaries & 2,004 & 14.08 & 2.81 & 4 & 31 \\
Ovulation rate at fertilization & & & & & \\
$\quad$ Left ovary & 1,866 & 8.64 & 2.54 & 0 & 23 \\
Right ovary & 1,866 & 7.95 & 2.51 & 0 & 37 \\
$\quad$ Both ovaries & 1,866 & 16.66 & 3.11 & 4 & 100 \\
Prenatal survival, \% & 1,676 & 62.6 & 18.4 & 5.3 & 100 \\
Corrected prenatal survival, \% & 1,676 & 62.7 & 17.4 & 5.7 & 18 \\
Total number born & 1,798 & 10.26 & 2.88 & 1 & \\
\hline
\end{tabular}

nary analyses, but they were all nonsignificant. Responses to selection were estimated as the differences between the average performance of animals in selected lines and the average performance in the control line at each generation. Approximate SE of responses to selection were computed, accounting for drift and measurement error variances (Hill, 1972). A similar procedure to that employed by Neal et al. (1989) was used to estimate realized heritabilities.

Mixed Models Analyses. Variance components were first estimated using REML methodology (Patterson and Thompson, 1971) applied to a multivariate animal model. The models used to describe the different traits analyzed are shown in Table 2 . All traits were considered as sow traits. Common birth litter and sow permanent environmental effects were fitted as uncorrelated random effects. The analyses were performed using VCE (Neumaier and Groeneveld, 1998) and ASREML (Gilmour et al., 2002) computer packages. The BLUP estimated breeding values were then computed as backsolutions of the REML analyses. Responses to selection were estimated from the within-generation line difference (selected - control) of average estimated breeding values of animals recorded for the trait analyzed or by contrasting coefficients of regression of estimated breeding values on generation number within each line. Because no selection occurred in the seventh generation, it was grouped with the sixth generation to compute the coefficients of regression on generation number. The variance of these within-generation differences and regression coefficients was computed from the animal by animal part of the inverse of the coefficient matrix from the mixed models equations at convergence for variance components, as described by, for example, Johnson et al. (1999).

\section{RESULTS}

The REML estimates of genetic parameters are shown in Table 3. Ovulation rate at puberty and at fertilization had rather high heritability values. The number of corpora on each ovary was much less heritable, with significantly greater values on the left than on the right ovary at puberty and fertilization. Low, but significant, heritabilities were obtained for prenatal survival, corrected prenatal survival, and litter size traits at birth. Common litter effects, which include a large part of dominance effects (Johansson et al., 1994),

Table 2. Models used to estimate genetic parameters and genetic responses to selection

\begin{tabular}{|c|c|c|c|c|c|c|c|c|c|}
\hline \multirow[b]{3}{*}{ Trait $^{1}$} & \multicolumn{4}{|c|}{ Covariate } & \multirow{2}{*}{\multicolumn{2}{|c|}{ Fixed effect }} & \multirow{2}{*}{\multicolumn{3}{|c|}{ Random effect }} \\
\hline & \multicolumn{3}{|c|}{ Age of the dam at } & \multirow{2}{*}{$\frac{\text { Dam }}{\text { Inbreeding }}$} & & & & & \\
\hline & Puberty & Fert $^{2}$ & Farrowing & & $\begin{array}{l}\text { Contemporary } \\
\text { group }\end{array}$ & $\begin{array}{l}\text { Parity } \\
\text { number }\end{array}$ & $\begin{array}{l}\text { Common } \\
\text { birth litter }\end{array}$ & $\begin{array}{l}\text { Permanent } \\
\text { environment }\end{array}$ & Animal \\
\hline ORPL & $\mathrm{x}$ & & & & $\mathrm{x}$ & & $\mathrm{x}$ & & $\mathrm{x}$ \\
\hline ORPR & $\mathrm{x}$ & & & & $\mathrm{x}$ & & $\mathrm{x}$ & & $\mathrm{x}$ \\
\hline ORP & $\mathrm{x}$ & & & & $\mathrm{x}$ & & $\mathrm{x}$ & & $\mathrm{x}$ \\
\hline ORF & & $\mathrm{x}$ & & & $\mathrm{x}$ & $\mathrm{x}$ & $\mathrm{x}$ & $\mathrm{x}$ & $\mathrm{x}$ \\
\hline PS & & $\mathrm{x}$ & & & $\mathrm{x}$ & $\mathrm{x}$ & $\mathrm{x}$ & $\mathrm{x}$ & $\mathrm{x}$ \\
\hline CPS & & $\mathrm{x}$ & & $\mathrm{x}$ & $\mathrm{x}$ & $\mathrm{x}$ & $\mathrm{x}$ & $\mathrm{x}$ & $\mathrm{x}$ \\
\hline TNB & & & $\mathrm{x}$ & $\mathrm{x}$ & $\mathrm{x}$ & $\mathrm{x}$ & $\mathrm{x}$ & $\mathrm{x}$ & $\mathrm{x}$ \\
\hline
\end{tabular}

${ }^{1}$ ORPL, ORPR, ORP = ovulation rate at puberty in the left, right, and both ovaries, respectively; ORFL, ORFR, ORF = ovulation rate at fertilization in the left, right, and both ovaries, respectively; PS = prenatal survival; CPS = prenatal survival corrected for ovulation rate; $\mathrm{TNB}=$ total number of piglets born per litter.

${ }^{2}$ Age of the dam at fertilization. 
Table 3. Estimates of heritability, common birth litter effects, permanent environmental effects, and phenotypic SD

\begin{tabular}{|c|c|c|c|c|}
\hline Trait $^{1}$ & Heritability $^{2}$ & $\begin{array}{c}\text { Common } \\
\text { litter } \\
\text { effect }^{2}\end{array}$ & $\begin{array}{c}\text { Permanent } \\
\text { environment }^{2}\end{array}$ & $\begin{array}{c}\text { Phenotypic } \\
\text { SD }\end{array}$ \\
\hline ORPL & 0.17 & 0.02 & - & 2.33 \\
\hline ORPR & 0.11 & 0.03 & - & 2.43 \\
\hline ORP & 0.34 & 0.03 & - & 2.59 \\
\hline ORFL & 0.13 & 0.00 & 0.00 & 2.46 \\
\hline ORFR & 0.09 & 0.03 & 0.03 & 2.43 \\
\hline ORF & 0.33 & 0.03 & 0.01 & 2.80 \\
\hline PS, \% & 0.14 & 0.04 & 0.02 & 18.0 \\
\hline CPS, \% & 0.11 & 0.02 & 0.07 & 17.4 \\
\hline TNB & 0.17 & 0.01 & 0.09 & 2.85 \\
\hline
\end{tabular}

${ }^{1} \mathrm{ORPL}, \mathrm{ORPR}, \mathrm{ORP}=$ ovulation rate at puberty in the left, right, and both ovaries, respectively; ORFL, ORFR, ORF = ovulation rate at fertilization in the left, right, and both ovaries, respectively; PS = prenatal survival; CPS = prenatal survival corrected for ovulation rate; $\mathrm{TNB}=$ total number of piglets born per litter.

${ }^{2}$ Parameter SE ranged from 0.01 to 0.03 .

were low for all traits investigated. Permanent environmental effects were also low for ovulation rate measurements and prenatal survival but much greater for litter size at birth.

Estimates of phenotypic and genetic correlations are shown in Table 4. The number of corpora lutea on the left and the right ovaries presented negative phenotypic correlations at puberty and fertilization $(-0.40$ and -0.30 , respectively). The other phenotypic correlations between ovulation rate measurements were weakly positive (0.09 to 0.33 ), except between the numbers of corpora lutea on each ovary and total ovulation rate, which had stronger relationships (0.51 to 0.58). Conversely, genetic correlations between the different ovulation rate measurements were all highly positive $(0.72$ to 0.99 ). Similarly, the phenotypic and genetic correlations between PS and CPS were close to unity (0.96 and 0.95 , respectively).

Ovulation rate measurements had negative (i.e., antagonistic) phenotypic and genetic relationships with
PS. The antagonism was low at puberty $\left(r_{p}=-0.05\right.$ to $-0.18 ; r_{g}=-0.11$ to -0.34$)$, but stronger at fertilization, with phenotypic correlations ranging from -0.23 to -0.36 and genetic correlations ranging from -0.45 to -0.66 . The CPS had weak phenotypic correlations with the various OR measurements $\left(\left|\mathrm{r}_{\mathrm{p}}\right| \leq 0.12\right)$. Genetic correlations were also low with ovulation at puberty $\left(\left|r_{\mathrm{g}}\right|\right.$ $\leq 0.08$ ) but were moderately negative at fertilization (from -0.31 to -0.42 ). Phenotypic correlations between ovulation rate measurements and litter size at birth were all low $(<0.22)$. With the exception of the large values obtained for ORPR $\left(r_{g}=0.62\right)$, genetic correlations between OR measurements and TNB were moderately positive at puberty $\left(\mathrm{r}_{\mathrm{g}}=0.30\right.$ to 0.42$)$ and fertilization $\left(r_{\mathrm{g}}=0.18\right.$ to 0.41$)$. Conversely, litter size at birth had very strong phenotypic (0.82) and genetic (0.66) correlations with prenatal survival.

Least squares (LS) and mixed models (MM) estimates of responses to selection for ORP, ORF, PS, CPS, and TNB are shown in Figures 1 to 5. Regression coefficients of response to selection on generation number for the 9 traits analyzed are given in Table 5. The LS and MM estimates of response to selection were very similar, except for ORFL, ORFR, and ORF, where MM estimates were slightly lower than LS estimates (e.g., 0.43 vs. 0.60 for the regression coefficient of ORF response on generation number).

Ovulation rate at puberty and at fertilization increased at a similar rate from generation 1 to 6 but slightly decreased in generation 7 in OR line. Regression coefficients of response to selection on generation number were superior to 0.5 corpora lutea for both traits. The realized heritability for ORP $\left(\hat{\mathbf{h}}_{\mathbf{r}}^{2}=0.37 \pm\right.$ $0.08)$ was highly significant $(P<0.001)$. The response to selection tended to be larger in the left than in the right ovary both at puberty and at fertilization $(+0.25$ \pm 0.09 vs. $+0.19 \pm 0.10$ and $+0.22 \pm 0.10$ vs. $+0.17 \pm 0.10$, respectively). Ovulation rate at puberty also tended to increase in the PS line $(P<0.10)$, with an improvement that mainly occurred during the first 3 generations (Figure 1). Conversely, no significant trend was observed for ORF in the PS line.

Table 4. Estimates ${ }^{1}$ of phenotypic (below diagonal) and genetic (above diagonal) correlations between components of litter size

\begin{tabular}{lcccccccrr}
\hline \hline Trait $^{2}$ & ORPL & ORPR & ORP & ORFL & ORFR & ORF & PS & CPS & TNB \\
\hline ORPL & - & 0.72 & 0.94 & 0.78 & 0.88 & 0.78 & -0.34 & -0.08 & 0.30 \\
ORPR & -0.40 & - & 0.91 & 0.72 & 0.84 & 0.81 & -0.11 & 0.07 & 0.62 \\
ORP & 0.58 & 0.51 & - & 0.83 & 0.95 & 0.89 & -0.26 & -0.02 & 0.41 \\
ORFL & 0.16 & 0.13 & 0.26 & - & 0.99 & 0.99 & -0.66 & -0.31 & 0.24 \\
ORFR & 0.10 & 0.09 & 0.17 & -0.30 & - & 0.99 & -0.58 & -0.41 & 0.40 \\
ORF & 0.22 & 0.18 & 0.33 & 0.51 & 0.57 & - & -0.45 & -0.42 & 0.41 \\
PS & -0.05 & -0.08 & -0.18 & -0.23 & -0.22 & -0.36 & - & 0.95 & 0.66 \\
CPS & -0.12 & 0.00 & -0.04 & -0.08 & -0.07 & -0.01 & 0.96 & - & 0.79 \\
TNB & 0.06 & 0.01 & 0.06 & 0.10 & 0.10 & 0.21 & 0.82 & 0.93 & - \\
\hline
\end{tabular}

${ }^{1} \mathrm{SE}$ of genetic correlation estimates ranged from 0.03 to 0.13 .

${ }^{2}$ ORPL, ORPR, ORP = ovulation rate at puberty in the left, right, and both ovaries, respectively; ORFL, ORFR, ORF = ovulation rate at fertilization in the left, right, and both ovaries, respectively; PS = prenatal survival; $\mathrm{CPS}=$ prenatal survival corrected for ovulation rate; $\mathrm{TNB}=$ total number of piglets born per litter. 

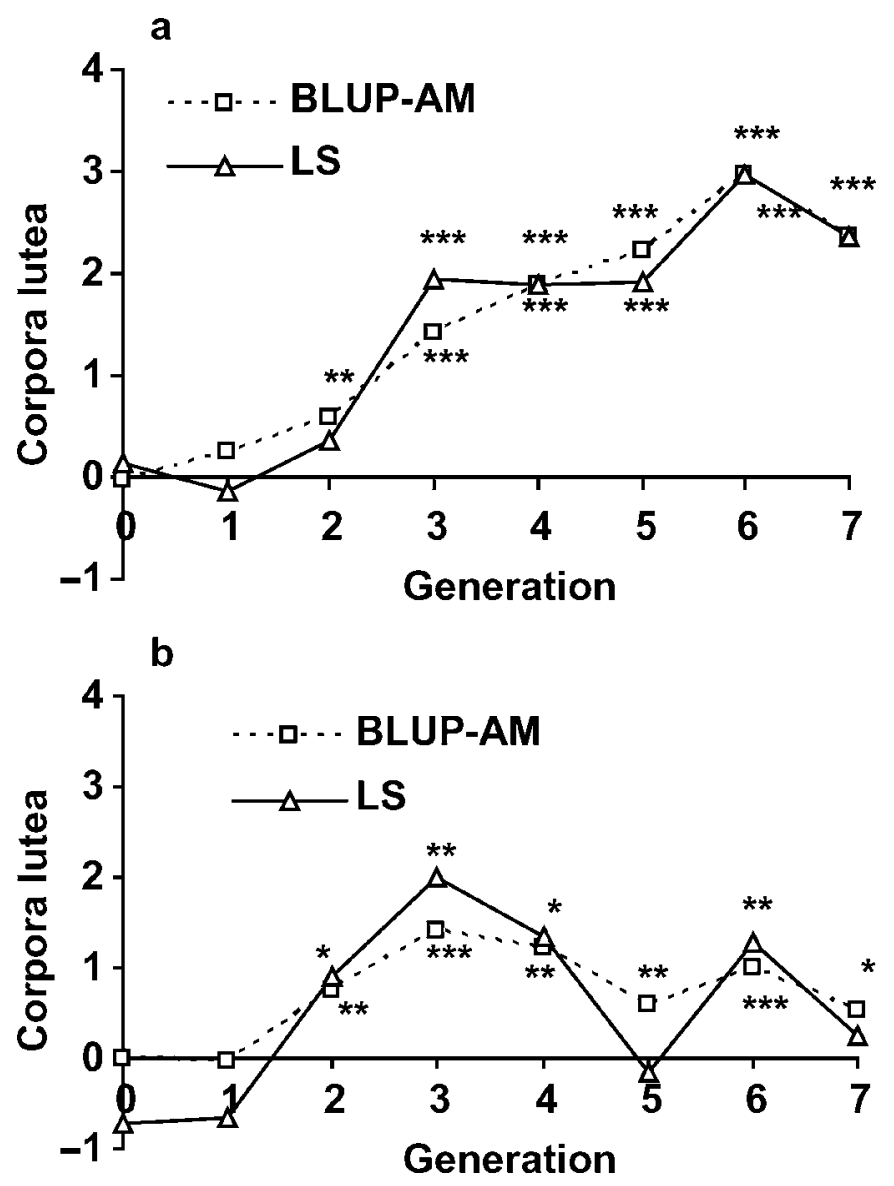

Figure 1. Differences (selected minus control line) in phenotypic least squares (LS) means and average breeding value (BLUP-AM) plotted by generation for ovulation rate at puberty between the line selected for ovulation rate at puberty (a) or prenatal survival (b) and the unselected control line. ${ }^{*} P<0.05 ;{ }^{* *} P<0.01 ;{ }^{* * *} P<0.001$.

Contrary to ovulation rate, prenatal survival did not show any significant trend in the PS line and was associated with a nonsignificant estimate of the realized heritability $\left(\hat{\mathbf{h}}_{\mathbf{r}}^{2}=0.10 \pm 0.09\right)$. An unfavorable trend $(P<$ 0.10 ) was obtained for CPS and PS in the in the OR line, particularly in generations 4 and 5 (Figure 3).

Litter size at birth remained almost constant in the OR line but significantly improved in the PS line $(+0.24$ \pm 0.11 piglet/generation, Figure 4).

\section{DISCUSSION}

The primary objective of the experiment was to obtain estimates of genetic parameters of components of litter size in order to predict the potential interest of selecting on these components. Heritability estimates for ORP and ORF are moderate and close to average literature values (Rothschild and Bidanel, 1998). They indicate that ovulation rate can rather easily be improved by selection, as shown by the significant direct responses obtained in the OR line. This positive result is in agreement with the results from previous experiments
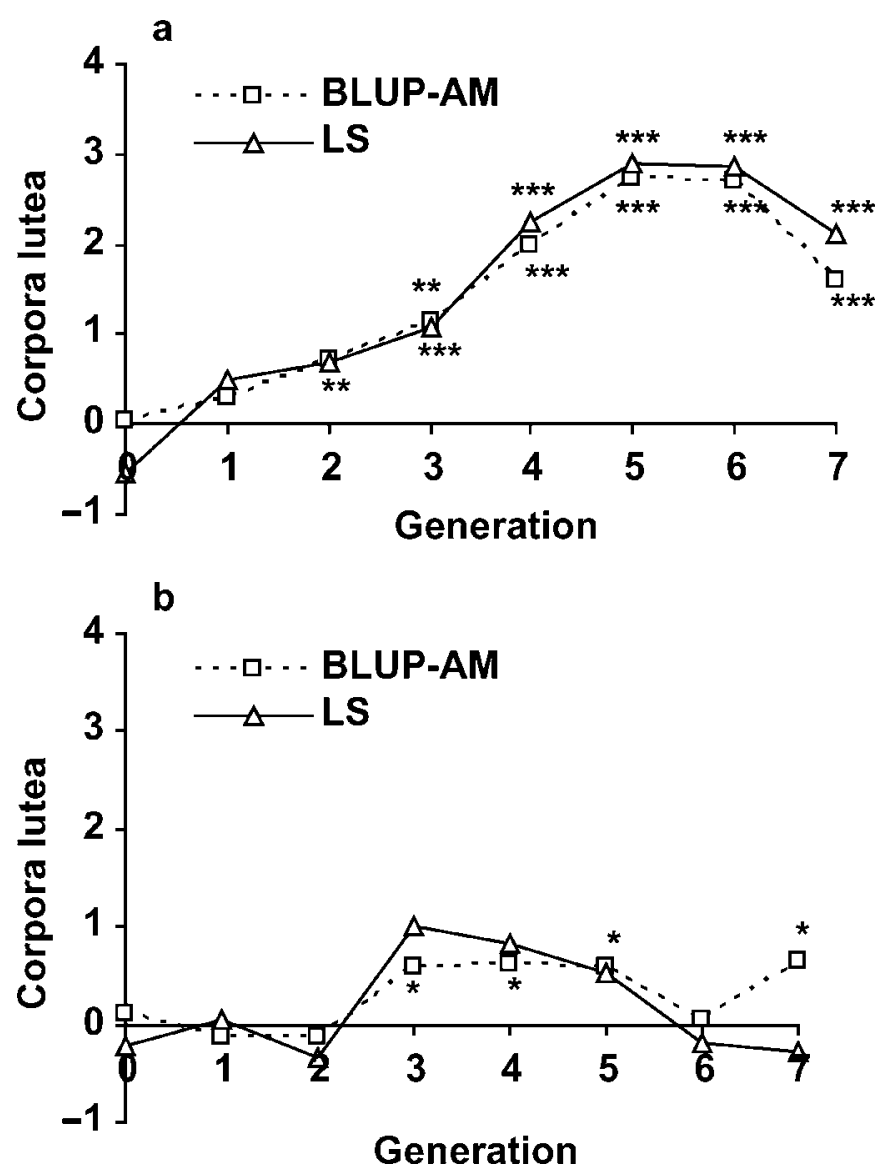

Figure 2. Differences (selected minus control line) in phenotypic least squares (LS) means and average breeding value (BLUP-AM) plotted by generation for ovulation rate at fertilization between the line selected for ovulation rate at puberty (a) or prenatal survival (b) and the unselected control line. ${ }^{*} P<0.05$; ${ }^{* *} P<0.01$; ${ }^{* * *} P<0.001$.

in mice (Bradford, 1969; Land and Falconer, 1969) and in pigs (Zimmerman and Cunningham, 1975), although realized heritabilities somewhat differed between studies: 0.39 in our study vs. 0.31 (Land and Falconer, 1969) and 0.10 (Bradford, 1969) in mice and 0.42 (Cunningham et al., 1979) in pigs. The larger heritability values in the left than in the right ovary agrees with the only result available in the literature (i.e., that of Nielsen et al., 1996) in mice, who also found greater heritability values for the number of corpora lutea and uterine capacity on the left than on the right side. They may indicate a more prominent role of the left ovary in the set of interactions between ovaries. These interactions appear as mainly of environmental origin because genetic correlations between left and right ovulation rates are close to unity, thus indicating a common genetic determinism. They may reflect a negative control of ovulation rate between ovaries, which would result to some extent in a limitation of the total number of ova shed.

Genetic correlations between ovulation rate measurements at puberty and at fertilization were high: 
a

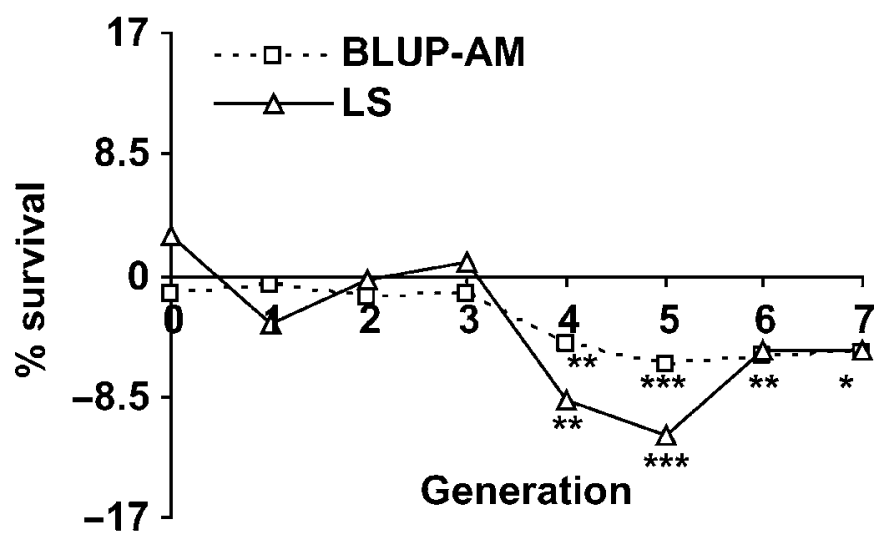

b

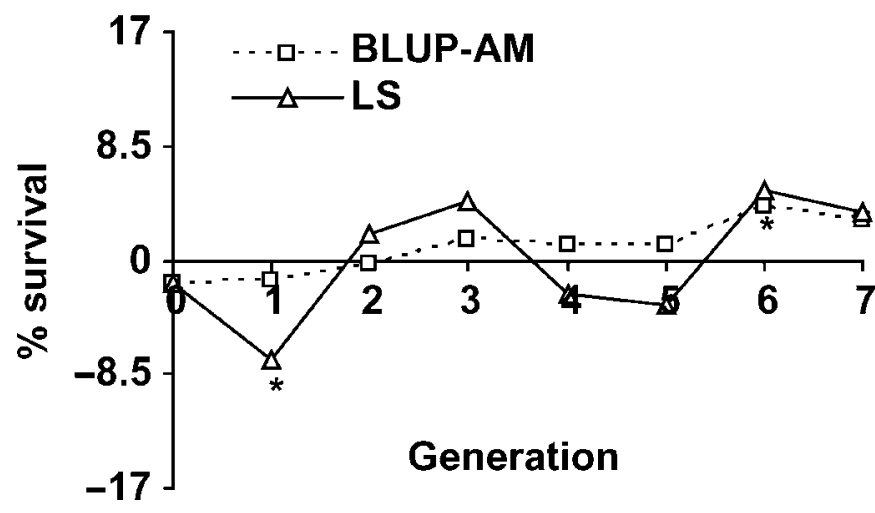

Figure 3. Differences (selected minus control line) in phenotypic least squares (LS) means and average breeding value (BLUP-AM) plotted by generation for prenatal survival between the line selected for ovulation rate at puberty (a) or prenatal survival (b) and the unselected control line. ${ }^{*} P<0.05 ;{ }^{* *} P<0.01 ;{ }^{* * *} P<0.001$.

estimates ranged from 0.72 to 0.95 and generally did not differ from unity. The 2 measurements thus have a largely common genetic determinism, though ORP is estimated at a constant physiological stage (i.e., puberty), whereas ORF is basically measured at a constant age. This common genetic determinism is confirmed by the strong correlative response of ORF to selection for ORP.

The heritability of prenatal survival was significant but much lower than that of ovulation rate and of the same order of magnitude as that of litter size at birth ( 0.14 vs. 0.17 for total number born). It indicates that some genetic variation exists for prenatal survival but that it explains only a limited fraction of the phenotypic variability. The estimate is similar to that obtained by Johnson et al. (1999) at $50 \mathrm{~d}$ of gestation but larger than the values reported by Gama et al. (1991) also at $50 \mathrm{~d}$ of gestation, Bidanel et al. (1996) at $30 \mathrm{~d}$ of gestation, and above all Haley and Lee (1992), who obtained no genetic variation in prenatal survival. This low heritability value is a potential explanation for the lack of significant direct response to selection for PS, although
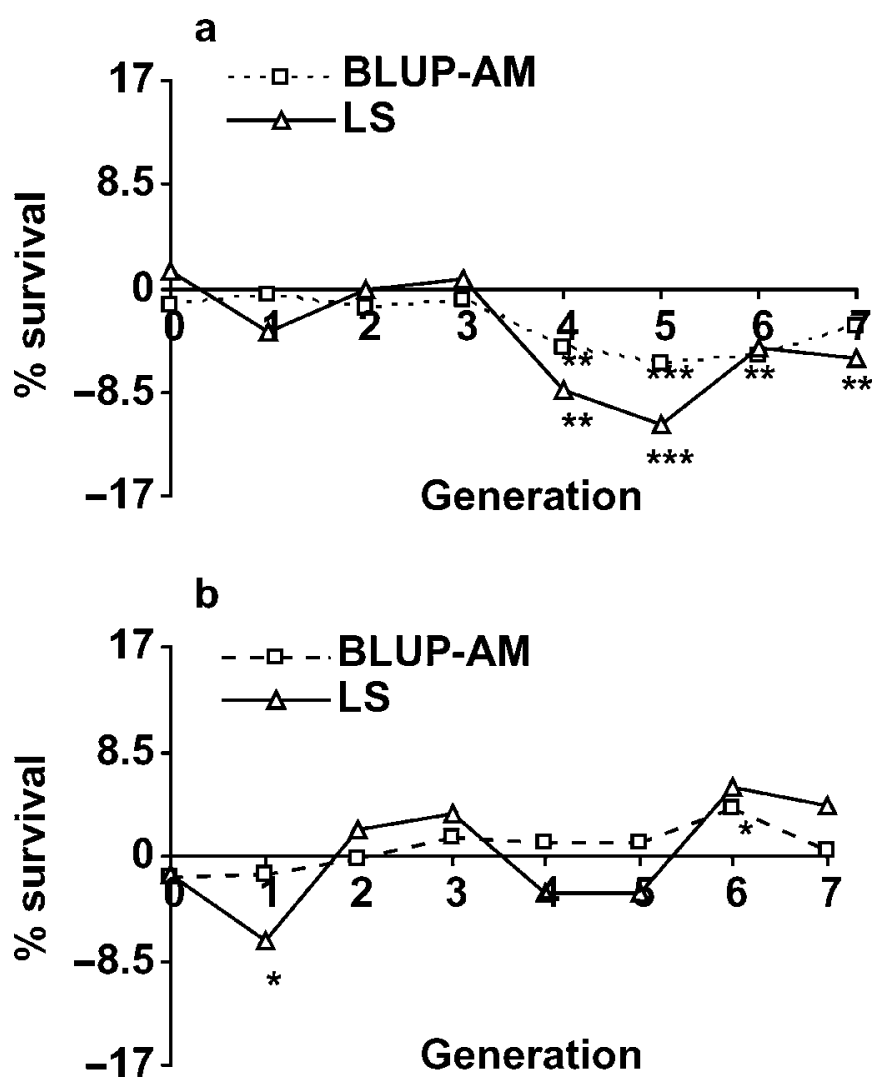

Figure 4. Differences (selected minus control line) in phenotypic least squares (LS) means and average breeding value (BLUP-AM) plotted by generation for corrected prenatal survival between the line selected for ovulation rate at puberty (a) or prenatal survival (b) and the unselected control line. ${ }^{*} P<0.05 ;{ }^{*} P<0.01 ;{ }^{* *} P<0.001$.

the experiment had a power of almost $80 \%$ for a heritability value of 0.14 for CPS. Other elements, such as the greater increase of inbreeding in the PS than in the other lines or the complexity of the selection criterion used, may also explain the lack of significant direct response to selection. Indeed, the selection criterion, CPS, was a 2-trait index involving OR and PS, this latter trait being defined as a ratio. A significant response to selection on prenatal survival was obtained by (Bradford, 1969) using a ratio trait as a selection criterion. Yet, response to selection on ratio traits has been shown through simulation studies to be difficult to predict and may substantially differ from expectation (Gunsett, 1987; Krieter and Presuhn, 1997). Then, the phenotypic and genetic correlations between ORF and PS were stronger than the average literature values (Bidanel, 1989) used to compute the selection index (respectively, -0.36 and -0.45 vs. -0.25 and -0.40 ). These larger than expected correlations and the use of wrong genetic parameters (Sales and Hill, 1976) might both have contributed to a reduced response to selection.

The genetic antagonism between ovulation rate at fertilization and the subsequent prenatal survival was 

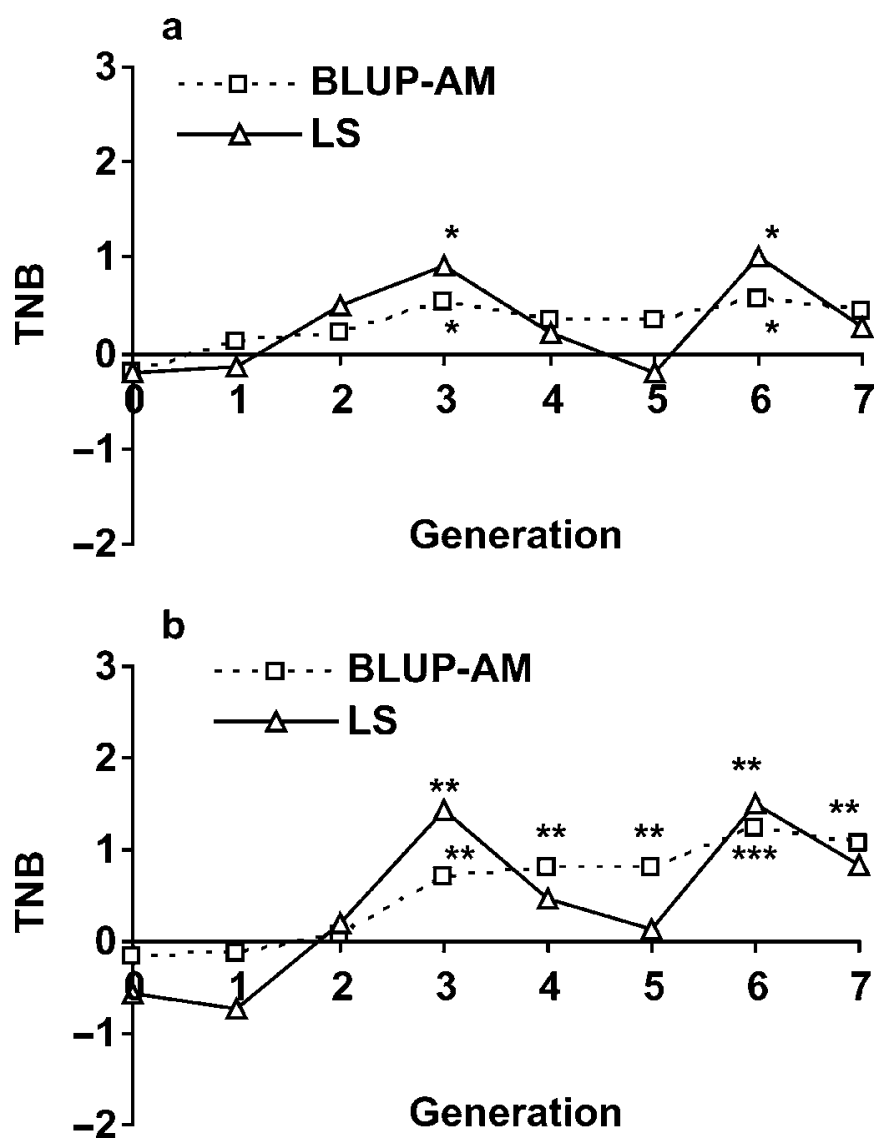

Figure 5. Differences (selected minus control line) in phenotypic least squares (LS) means and average breeding value (BLUP-AM) plotted by generation for total number born (TNB) between the line selected for ovulation rate at puberty (a) or prenatal survival (b) and the unselected control line. ${ }^{*} P<0.05 ;{ }^{* *} P<0.01 ;{ }^{* *} P<0.001$. indeed slightly stronger than the average literature value at the beginning of the experiment (Bidanel, 1989), but a wide range of estimates have been reported since then. Low values were reported for embryo survival rate at $30 \mathrm{~d}$ of gestation (Young et al., 1977; Bolet et al., 1989; Bidanel et al., 1996), whereas strongly negative values ( -0.56 and -0.86 , respectively) were reported by Neal et al. (1989) and Johnson et al. (1999) at $50 \mathrm{~d}$ of gestation. In rabbits, Blasco et al. (2005) obtained a moderate genetic correlation between ovulation and prenatal survival (-0.37). They additionally showed that survival rates during the 2 main stages of prenatal life (i.e., embryonic and fetal periods) have a completely different genetic determinism. Ovulation rate had a strongly positive genetic correlation (0.61) with embryo survival but a negative one with fetal survival $(-0.63)$. This result is a clear indication of an increased uterine competition throughout gestation. An increased competition has also been shown in pigs by superovulation and embryo transfer experiments (Dziuk, 1968; Pope et al., 1972; Webel and Dziuk, 1974) or more recently by experiments on unilaterally hystero-ovariectomized females (Christenson et al., 1987; Legault et al., 1995). However, as evidenced in rabbits by Argente et al. (1997), competition between embryos after implantation does not solely explain variations in litter size, which also largely depend on the pre- or periimplantatory periods.

Litter size at birth had positive genetic correlations with ovulation rate and prenatal survival measurements but with stronger values for these latter traits (0.66 and 0.79 with PS and CPS, respectively). The moderate genetic correlations between $\mathrm{OR}$ and TNB are very similar to the values obtained at $50 \mathrm{~d}$ of gestation in the Nebraska experiment (Neal et al., 1989) but are lower than the estimates obtained by Young et al. (1977), Bolet et al. (1989), and Bidanel et al. (1996) at $30 \mathrm{~d}$ of gestation. The strong genetic correlations between PS and litter size at birth agree with the esti-

Table 5. Least squares and mixed models estimates of the response to selection

\begin{tabular}{lccccc}
\hline \hline & \multicolumn{3}{c}{ OR line } & & \multicolumn{2}{c}{ PS line } \\
\cline { 2 - 3 } \cline { 5 - 6 } Trait $^{1}$ & $\begin{array}{c}\text { Least squares } \\
\text { estimate }^{2}\end{array}$ & $\begin{array}{c}\text { Mixed models } \\
\text { estimate }\end{array}$ & & $\begin{array}{c}\text { Least squares } \\
\text { estimate }\end{array}$ & $\begin{array}{c}\text { Mixed models } \\
\text { estimate }\end{array}$ \\
\hline ORPL & $0.27(0.09)$ & $0.25(0.09)$ & & $-0.03(0.09)$ & $-0.03(0.09)$ \\
ORPR & $0.24(0.10)$ & $0.19(0.10)$ & & $0.20(0.10)$ & $0.12(0.10)$ \\
ORP & $0.51(0.10)$ & $0.49(0.10)$ & & $0.16(0.10)$ & $0.11(0.10)$ \\
ORFL & $0.35(0.10)$ & $0.22(0.10)$ & & $0.10(0.10)$ & $0.06(0.10)$ \\
ORFR & $0.27(0.10)$ & $0.17(0.10)$ & & $-0.03(0.10)$ & $0.05(0.10)$ \\
ORF & $0.60(0.11)$ & $0.43(0.11)$ & & $0.04(0.11)$ & $0.11(0.11)$ \\
PS, \% & $-1.6(0.9)$ & $-1.0(0.9)$ & & $1.0(0.9)$ & $0.8(0.9)$ \\
CPS, $\%$ & $-1.4(0.8)$ & $-1.4(0.8)$ & $0.9(0.8)$ & $0.8(0.8)$ \\
TNB & $0.06(0.11)$ & $0.08(0.11)$ & $0.21(0.11)$ & $0.24(0.11)$ \\
\hline
\end{tabular}

${ }^{1}$ ORPL, ORPR, ORP = ovulation rate at puberty in the left, right, and both ovaries, respectively; ORFL, $\mathrm{ORFR}, \mathrm{ORF}=$ ovulation rate at fertilization in the left, right, and both ovaries, respectively; PS = prenatal survival; CPS = prenatal survival corrected for ovulation rate; TNB = total number of piglets born per litter.

${ }^{2}$ Regression of generation $\times$ line differences (selected minus control lines) on generation number.

${ }^{3}$ Differences (selected minus control lines) between regression coefficients of estimated breeding values on generation number. 
mates obtained in the Nebraska experiment (Neal et al., 1989) and with estimates obtained in rabbits and mice (Clutter et al., 1990; Blasco et al., 1993). These favorable genetic correlations are in line with the significant improvement in TNB in the PS line. Based on the genetic parameters from this study, the observed response (LS estimate of $0.22 \pm 0.10$ piglet/generation) is close to the predictive correlative response $(0.24$ piglet/generation) but is clearly inferior to the predictive response to a direct selection on TNB ( 0.40 piglet/generation). It is also very similar to the response obtained after 14 generations in the Nebraska selection experiment on an index combining OR and embryo survival $(0.21 \pm 0.04$ piglet/generation; Johnson et al., 1999), although the indexes used put a much greater weight on ES than on PS in the present experiment (the ratio of index weights $\mathrm{W}_{\mathrm{ES}} / \mathrm{W}_{\mathrm{OR}}$ was successively 6.8 and 15.0 in the Nebraska vs. 1.8 in the French experiment). The reason for this large difference is that the objectives were not the same; the Nebraska experiment aimed at selecting on an index maximizing response on litter size at birth, whereas the French one aimed at selecting on PS while maintaining OR at a constant level. The actual response slightly differed from expectations because the improvement of litter size was partly due to a small (LS estimate) to moderate (MM estimate) increase in ORF.

Conversely, in spite of the positive genetic correlations between ovulation rate and litter size, no correlative response on litter size at birth was obtained from selection for an increased ovulation rate. This lack of response is related to the negative genetic correlation between OR and PS but may have several explanations from a physiological viewpoint. Uterine capacity, i.e., the maximum number of fetuses the sow can carry up to term, may limit the efficiency on selection on ovulation rate (Bennett and Leymaster, 1990; Perez-Enciso et al., 1996; Perez-Enciso and Bidanel, 1997). An increase in fetal loss is expected in this situation. Yet, other causes such as an increased proportion of immature oocytes, a greater asynchrony between uterus and embryos, resulting in embryo rather than fetal losses, may also explain the lack of correlative response on litter size.

The genetic parameters obtained in this study can be used to predict the relative efficiency of selection on an index combining OR and PS vs. direct selection on litter size. Based on the model developed by Perez-Enciso et al. (1996), the predicted superiority of the index over direct selection would be only a few percent in the French Large White population. Given the extra costs associated with ovulation rate measurement, the interest of selecting on components of litter size appear rather limited in this large population where alternative selection strategies such as hyperprolific selection can easily be implemented.

\section{IMPLICATIONS}

These results confirm that ovulation rate is moderately heritable and can easily be improved through se- lection but without any correlated response on litter size. They also show that a limited but significant genetic variation of prenatal survival exists in French Large White population. Selecting for an improved prenatal survival or an index combining ovulation rate and prenatal survival is effective in improving litter size at birth. Yet, predicted genetic trends based on estimated genetic parameters of components of litter size in this population tend to show that the superiority of selecting on an index combining ovulation rate and prenatal survival is limited, so that this selection strategy cannot be recommended in this population.

\section{LITERATURE CITED}

Argente, M. J., M. A. Santacreu, A. Climent, G. Bolet, and A. Blasco. 1997. Divergent selection for uterine capacity in rabbits. J. Anim. Sci. 75:2350-2354.

Bennett, G. L., and K. A. Leymaster. 1990. Genetic implications of a simulation model of litter size in swine based on ovulation rate, potential embryonic viability and uterine capacity: I. Simulated selection. J. Anim. Sci. 68:980-986.

Bidanel, J. P. 1989. Ovulation rate and prenatal survival in pigs: Genetic aspects. Productions Animales, INRA 2:159-170.

Bidanel, J. P., J. Gruand, and C. Legault. 1994. An overview of twenty years of selection for litter size in pigs using "hyperprolific" schemes. Proc. 5th World Congr. Genet. Appl. Livest. Prod., Guelph, Ontario, Canada 17:512-515.

Bidanel, J. P., J. Gruand, and C. Legault. 1996. Genetic variability of age and weight at puberty, ovulation rate and embryo survival in gilts and relationship with production traits. Genet. Sel. Evol. 28:103-115.

Blasco, A., J. P. Bidanel, G. Bolet, C. S. Haley, and M. A. Santacreu. 1993. The genetics of prenatal survival of pigs and rabbits-A review. Livest. Prod. Sci. 37:1-21.

Blasco, A., J. A. Ortega, A. Climent, and M. A. Santacreu. 2005. Divergent selection for uterine capacity in rabbits. I. Genetic parameters and response to selection. J. Anim. Sci. 83:22972302.

Bolet, G., L. Ollivier, and P. Dando. 1989. Selection for prolificacy in pigs. 1. Results of a selection experiment over 11 generations. Genet., Sel., Evol. 21:93-106.

Bradford, G. E. 1969. Genetic control of ovulation rate and embryo survival in mice. I-response to selection. Genetics 61:905-921.

Christenson, R. K., K. A. Leymaster, and L. D. Young. 1987. Justification of unilateral hysterectomy-ovariectomy as a model to evaluate uterine capacity in swine. J. Anim. Sci. 65:738-744.

Clutter, A. C., M. K. Nielsen, and R. K. Johnson. 1990. Alternative methods of selection for litter size in mice: I. Characterization of base population and development of methods. J. Anim. Sci. 68:3536-3542.

Cunningham, P. J., M. E. England, L. D. Young, and D. R. Zimmerman. 1979. Selection for ovulation rate in swine: Correlated response in litter size and weight. J. Anim. Sci. 48:509-516.

de Vries, A. G. 1989. A model to estimate economic values of traits in pig breeding. Livest. Prod. Sci. 21:49-66.

Dziuk, P. J. 1968. Effect of number of embryos and uterine space on embryo survival in the pig. J. Anim. Sci. 27:673-676.

Gama, L. T., K. G. Boldman, and R. K. Johnson. 1991. Estimates of genetic parameters for direct and maternal effects on embryonic survival in swine. J. Anim. Sci. 69:4801-4809.

Gilmour, A. R., B. J. Gogel, B. R. Cullis, S. J. Welham, and R. Thompson. 2002. Asreml user guide release 1.1. VSN International Ltd, Hemel Hempstead, UK.

Gunsett, F. C. 1987. Merit of utilizing the heritability of a ratio to predict the genetic change of a ratio. J. Anim. Sci. 65:936-942.

Haley, C. S., and G. J. Lee. 1992. Genetic factors contributing to variation in litter size in British Large White gilts. Livest. Prod. Sci. 30:99-113. 
Hill, W. G. 1972. Estimation of genetic change. I. General theory and design of control populations. Anim. Breed. Abstr. 40:1-15.

Holl, J. W., and O. W. Robison. 2003. Results from nine generations of selection for increased litter size in swine. J. Anim. Sci. 81:624-629.

Johansson, K., B. W. Kennedy, and M. Wilhemson. 1994. Precision and bias of estimated genetic parameters in the presence of dominance and inbreeding. Proc. 5th World Congr. Genet. Appl. Livest. Prod., Guelph, Ontario, Canada 22:386-389.

Johnson, R. K., M. K. Nielsen, and D. S. Casey. 1999. Responses in ovulation rate, embryonal survival, and litter traits in swine to 14 generations of selection to increase litter size. J. Anim. Sci. 77:541-557.

Krieter, J., and U. Presuhn. 1997. The use of traits defined as products or ratios in pig breeding. Zuchtungskunde 69:130-141.

Land, R. B., and D. S. Falconer. 1969. Genetic studies of ovulation rate in the mouse. Genet. Res. 13:25-46.

Legault, C., J. C. Caritez, H. Lagant, and P. Popescu. 1995. Experimental study on the role of uterine space on embryonic and fetal viability. Influence of dam's genetic type. Journees de la Recherche Porcine en France 27:25-30.

Legault, C., and J. Gruand. 1976. Improvement of litter size in sows by the creation of a "hyperprolific" line and the use of artificial insemination: Theory and preliminary experimental results. Journées de la Recherche Porcine en France 8:201-212.

Mesa, H., T. J. Safranski, K. A. Fischer, K. M. Cammack, and W. R. Lamberson. 2005. Selection for placental efficiency in swine: Genetic parameters and trends. J. Anim. Sci. 83:983-991.

Neal, S. M., R. K. Johnson, and R. J. Kittok. 1989. Index selection for components of litter size in swine: Response to five generations of selection. J. Anim. Sci. 67:1933-1945.

Neumaier, A., and E. Groeneveld. 1998. Restricted maximum likelihood estimation of covariances in sparse linear models. Genet. Sel. Evol. 30:3-26.

Nielsen, M. K., Y. L. K. Kirby, and A. C. Clutter. 1996. Estimates of heritabilities and genetic and environmental correlations for left- and right-side uterine capacity and ovulation rate in mice. J. Anim. Sci. 74:529-534.
Patterson, H. D., and R. Thompson. 1971. Recovery of inter-block information when block sizes are unequal. Biometrika 58:545-554

Perez-Enciso, M., and J. P. Bidanel. 1997. Selection for litter size components: A critical review. Genet. Sel. Evol. 29:483-496.

Perez-Enciso, M., J. P. Bidanel, I. Baquedano, and J. L. Noguera. 1996. A comparison of alternative genetic models for litter size in pigs. Anim. Sci. 63:255-263.

Pope, C. E., R. K. Christenson, V. A. Zimmerman-Pope, and B. N. Day. 1972. Effect of number of embryos on embryonic survival in recipient gilts. J. Anim. Sci. 35:805-808.

Rothschild, M. F., and J. P. Bidanel. 1998. Biology and genetics of reproduction. Pages $313-343$ in The Genetics of the Pig. CAB International, Wallingford, UK.

Sales, J., and W. G. Hill. 1976. Effect of sampling errors on efficiency of selection indices. 2. Use of information on associated traits for improvement of a single important trait. Anim. Prod. 23:1-14.

Tess, M. W., G. L. Bennett, and G. E. Dickerson. 1983. Simulation of genetic changes in life cycle efficiency of pork production. II. Effects of components on efficiency. J. Anim. Sci. 56:354-368.

Tribout, T., J. C. Caritez, J. Gogué, J. Gruand, Y. Billon, M. Bouffaud, H. Lagant, J. Le Dividich, F. Thomas, H. Quesnel, R. Guéblez, and J. P. Bidanel. 2003. Estimation, par utilisation de semence congelée, du progrès génétique réalisé en france entre 1977 et 1998 dans la race porcine large white: Résultats pour quelques caractères de reproduction femelle. Journées de la Recherche Porcine en France 35:285-292.

Webel, S. K., and P. J. Dziuk. 1974. Effect of stage of gestation and uterine space on prenatal survival in the pig. J. Anim. Sci. 38:960-963.

Wilson, M. E., N. J. Biensen, and S. P. Ford. 1999. Novel insight into the control of litter size in pigs, using placental efficiency as a selection tool. J. Anim. Sci. 77:1654-1658.

Young, L. D., R. K. Johnson, and I. T. Omtvedt. 1977. An analysis of the dependency structure between a gilt's prebreeding and reproductive traits. I. Phenotypic and genetic correlations. J. Anim. Sci. 44:557-564.

Zimmerman, D. R., and P. J. Cunningham. 1975. Selection for ovulation rate in swine: Population, procedures and ovulation response. J. Anim. Sci. 40:61-69. 